\title{
The Provision of Haddul Kifayah for Shelter the Actual Cost of Shelter for Asnaf Faqr and Miskin: A Comparative Study
}

\author{
Sharina Farihah Hasan ${ }^{l, *}$ and Khairuddin Abdul Rashid ${ }^{l}$ \\ ${ }^{1}$ Kulliyyah of Architecture and Environmental Design, International Islamic University Malaysia
}

\begin{abstract}
Haddul kifayah is a method used by zakat authorities in determining eligibility for asnaf faqr and miskin to become recipient of zakat assistance. Within the haddul kifayah there is a component for the provision of shelter that includes cost for accommodation and its associated facilities and features. In the context of the provision of shelter, there has been growing concern that the provision allocated thereto has failed to meet the current cost incurred by asnaf faqr and miskin. Consequently a study to identify the subcomponents for shelter of the haddul-kifayah and the monetary allocations corresponding thereto and to examine whether the identified sub-components and their monetary allocations are appropriate and sufficient in meeting the recipients' current basic needs for shelter was carried out. The study adopted a combination of literature review and questionnaire survey. A total of 112 asnaf faqr and miskin located combination of literature review and questionnaire survey. A total of 112 asnaf faqr and miskin located
within the Federal Territory of Kuala Lumpur participated in the survey. The data collected from the survey was analysed using descriptive statistics. Results from the study identified the sub-components for shelter and their corresponding monetary allocations and confirmed the inadequacy in the provision of haddul kifayah for shelter both in terms of the amount allocated and the subcomponents thereto. The study is considered significant in two ways: (1) The study highlights the inadequacies on the provision of haddul kifayah for shelter, and; (2) The results may serve as an impetus for a comprehensive and national study on
\end{abstract} the provision of haddul kifayah for shelter to be conducted.

\section{Introduction}

Haddul kifayah refers to the level of income or earning of a household or an individual, adopted by zakat authorities, in establishing whether an individual or household fit into the category of asnaf faqr or asnaf miskin. Consequently, if they fit into any one of the said asnaf, the household or individual would be eligible to be given the necessary financial assistance via the zakat fund distribution.

Zakat is an obligatory form of worship (Ibadah) prescribed by Allah s.w.t. in the Quran (22:78) [1]: “.. Therefore, attend to your prayers and pay the alms-tax (zakat) and hold fast to Allah..." Hence, those who can afford more than sufficient basic needs should help the needy by donating through zakat contribution.

In Malaysia, Zakat is administered by the respective Majlis Agama Islam Negeri-negeri or MAIN (State Islamic Religious Councils or SIRCs). However, in 2004 Jabatan Wakaf, Zakat dan Haji (JAWHAR) or the Department of Awqaf, Zakat and Hajj was established by the Federal Government. The purpose of JAWHAR is to coordinate the activities of the respective MAINs and to improve the management of Muslim wealth in the forms of awqaf, zakat, mal and hajj [2]

The zakat monies collected are to be expended to the 8 categories of recipients (asnaf) and none others. The Quran (9:60) [1] identified them as the faqr (poor), miskin (needy), amil (zakat administrator), muallaf (newly muslim converts), riqab (slave), gharimin (those in debt), fisabilillah (those striving to maintain and increase appreciation of Islam) and ibnussabil (the wayfarer). The asnafs are given zakat assistances according to schemes provided by SIRCs. The assistance schemes include monthly financial, food, housing, medical and education [2-4].

This paper emphasises on the asnaf faqr and asnaf miskin. The distribution of zakat fund collection to eligible asnaf faqr and asnaf miskin is based on calculation of Haddul Kifayah.

Based on the authors' review of the calculations of haddul kifayah in the various states in Malaysia [5-6], the amount allocated is different from one state to another and as per allocated by the respective SIRCs in Malaysia.

Haddul kifayah consists of components that would enable a person to attain a reasonably comfortable standard of living. The key components are: shelter, food, clothing, medical, education and transportation [24]. Past studies such as the one by Khairuddin, Sharina and Azila [5] found out that the amount allocated for haddul kifayah was neither sufficient nor current. However, studies on the currency and sufficiency of the amount considered for the shelter component of the haddul kifayah are lacking.

In a pilot study aimed at comparing and contrasting the allocation of shelter in haddul kifayah provided by the SIRC of the Federal Territory of Kuala Lumpur and the actual and current cost incurred by the asnaf faqir and miskin was conducted in 2016 [6]. Results obtained

* Corresponding author: sfarihah@iium.edu.my 
from the pilot study suggested that the amount allocated is insufficient.

This paper reports on a study focussing on the provision of shelter under the haddul kifayah as adopted by Majlis Islam Wilayah Persekutuan Kuala Lumpur (MAIWP). MAIWP was chosen due to its convenient location and accessibility. The objectives set for the study are: (i) to identify the sub-components for the shelter in the haddul-kifayah and the monetary allocations corresponding thereto, and; (ii) to examine whether the identified sub-components and the monetary allocations corresponding thereto are appropriate and sufficient in meeting the current basic needs of shelter by the asnaf faqr and asnaf miskin respectively.

The paper is in 5 parts, Part 1 is the Introduction, and Part 2 describes the concept of haddul kifayah and the practice by MAIWP. Part 3 is the methodology adopted for the study, followed by Part 4 whereby results are discussed. The paper is ended by conclusion in Part 5.

\section{Haddul Kifayah}

MAIWP [3-4] defined haddul kifayah as minimum sufficiency line for basic needs of an individual and his dependants based on the current and actual cost of living.

The following Hadiths and the Fiqh-us-sunnah (the practice of sahabah) are some of the sources of reference on matters related to Shariah legitimacy on haddul kifayah. Narrated by Abu Huraira: "The poor person is not the one who goes around the people and ask them for a mouthful or two (of meals) or a date or two, but the poor is that who has not enough [money] to satisfy his needs and whose condition is not known to others, that others may give him something in charity and who he does not beg of people." (Hadith Shahih Bukhari: 2/24 no: 557 and Shahih Muslim: 005/32 no: 2261).

Another relevant hadith is: "...for him begging is permissible till he gets what will support life, or will provide him reasonable subsistence; and a person who has been smitten by poverty. The genuineness of which is confirmed by three intelligent members of this peoples for him begging is permissible till he gets what will support him, or will provide him subsistence... (Shahih Muslim: 005/34 no: 2271)

'Umar reported: "If you happen to give (alms), you should give to satisfv one's needs." (Figh-us-sunnah 3.60) [7].

The above references concluded that the amount required to cover basic needs varies from a household or an individual to another and that there is no universally established or specific amount for each of asnaf, whether they are categorized as faqr or miskin.

Haddul kifayah is calculated based on various variables such as the number of members in a household and age group of members in the household [2-4]. From the context of haddul kifayah [5-6], asnaf faqr and miskin are defined as follows:
- Faqr is an individual or a household who owns or do not own any asset or earns adequate amount of income to cover his/her daily basic needs (food, clothing, shelter, etc.) able to fulfil not more than $50 \%$ of his and his dependant's daily basic needs or the amount of haddul kifayah.

- Miskin is an individual or a household who has assets or income or earning to sustain only some portions of his daily basic needs but not enough for his and his dependants' daily basic needs.

In other words, faqr are those who are at less than $50 \%$ level, miskin are those earning higher than $50 \%$ whereas haddul kifayah is at $100 \%$ level [5-6].

\subsection{Components of Haddul Kifayah}

MAIWP [3] has listed the components of basic needs considered in the calculation of haddul kifayah.

Table 1. Components of haddul kifayah

\begin{tabular}{|l|l|}
\hline \multicolumn{1}{|c|}{ Components } & \multicolumn{1}{|c|}{ Description } \\
\hline $\begin{array}{l}\text { 1)Shelter/ } \\
\text { Accommodation }\end{array}$ & $\begin{array}{l}\text { Covering the costs for providing the } \\
\text { accommodation for the household } \\
\text { including house rent, utility bills and other } \\
\text { basic requirements for a living. }\end{array}$ \\
\hline 2)Food & $\begin{array}{l}\text { Any foods or drinks consumed by the } \\
\text { household }\end{array}$ \\
\hline 3)Clothing & $\begin{array}{l}\text { Any types of clothing worn by the } \\
\text { household, such as daily clothing, school } \\
\text { uniforms, work attire, etc. }\end{array}$ \\
\hline 4)Medical & $\begin{array}{l}\text { All forms of medical and equipment taken } \\
\text { by the household, i.e; treatment, pills and } \\
\text { medications procured from pharmacies, } \\
\text { etc. }\end{array}$ \\
\hline 5)Education & $\begin{array}{l}\text { All relevant expenditure for education, i.e; } \\
\text { school/college/university fees, books, etc. }\end{array}$ \\
\hline 6)Transportation & $\begin{array}{l}\text { Expenditures on transportation including } \\
\text { fuel, monthly instalment of the vehicle, } \\
\text { bus and/or taxi fare, etc. }\end{array}$ \\
\hline
\end{tabular}

$$
\text { Source: MAIWP [3] }
$$

Table 2 below presents the different categories of household members and the monthly rate calculation for Haddul Kifayah established by MAIWP. The table indicates that different calculation is applied for the head household. The rate is subjected to the type of housing they are residing. RM610 is allocated if they are paying house rental/servicing housing loan and RM310 if free housing (own or inherited).

Table 2. Categories of household members and the monthly rate calculation for Haddul Kifayah

\begin{tabular}{|l|c|c|}
\hline \multirow{2}{*}{ Household Category } & \multicolumn{2}{|c|}{$\begin{array}{c}\text { Haddul Kifayah } \\
\text { (RM)/person }\end{array}$} \\
\hline \multirow{2}{*}{$\begin{array}{l}\text { Head of Household (Working } \\
\text { adult) }\end{array}$} & $\begin{array}{c}\text { Paying rental } \\
\text { or home loan }\end{array}$ & $\begin{array}{c}\text { Free } \\
\text { housing }\end{array}$ \\
\cline { 2 - 3 } & 610 & 310 \\
\hline Spouse; unemployed & \multicolumn{2}{|c|}{170} \\
\hline School (15-18 years old) & \multicolumn{2}{|c|}{264} \\
\hline School (7-14 years old) & \multicolumn{2}{|c|}{204} \\
\hline Kindergarten (5 -6 years old) & \multicolumn{2}{|c|}{182} \\
\hline 4 years and below & \multicolumn{2}{|c|}{100} \\
\hline
\end{tabular}

Source: MAIWP [3] 
Table 3 presents the monthly additional rates for haddul kifayah. It is calculated based on the different conditions and problems facing the household.

Table 3. The schedule of monthly additional rate calculation for Haddul Kifayah

\begin{tabular}{|c|c|c|}
\hline No. & Description & $\begin{array}{c}\text { Haddul Kifayah } \\
\text { (RM)/person }\end{array}$ \\
\hline 1 & Critical illness & 200 \\
\hline 2 & Disable & 200 \\
\hline 3 & Single parent & 200 \\
\hline 4 & $\begin{array}{c}\text { Studying at Institution of Higher } \\
\text { Learning (Tertiary education) }\end{array}$ & 200 \\
\hline 5 & $\begin{array}{c}\text { Problematic family - husband } \\
\text { retained in prison, drug addict, } \\
\text { HIV, AIDS, etc. }\end{array}$ & 220 \\
\hline 6 & Child at day care & 200 \\
\hline \multicolumn{2}{|c|}{ Source: MAIWP [3] }
\end{tabular}

\subsubsection{Example of Calculation Based On Haddul} Kifayah

Example: A family consists of head household (employed), spouse (unemployed) and 4 children age 15 years old, 13 years old, 10 years old and 5 years old and they are living in a rented house. The total household income is RM810.00

Based on Table 4, haddul kifayah for the case is amounting to RM1, $634.00=\mathrm{RM} 610.00+\mathrm{RM} 170.00+$ RM264.00 + RM408.00 + RM182.00. Therefore, based on the category of asnaf, the applicant falls under the category of asnaf faqr. This is because their basic need is higher than the income. In addition, the household income (RM810.00) is lower than $50 \%$ of the basic needs (RM1, 634.00 / 2 = RM817.00).

Table 4. Example calculation of Haddul Kifayah for the family

\begin{tabular}{|c|c|c|c|c|c|}
\hline Basic Needs & 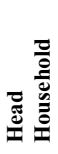 & $\frac{\bar{E}}{\bar{E}}$ & 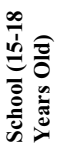 & 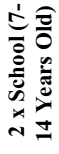 & 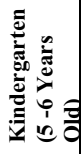 \\
\hline Shelter (RM) & 300 & - & - & - & - \\
\hline Food (RM) & 120 & 120 & 90 & 120 & 60 \\
\hline Clothing (RM) & 30 & 30 & 20 & 40 & 20 \\
\hline Medical (RM) & 20 & 20 & 20 & 40 & 20 \\
\hline Education (RM) & - & - & 44 & 88 & 22 \\
\hline $\begin{array}{l}\text { Transportation } \\
\text { (RM) }\end{array}$ & 140 & - & 90 & 120 & 60 \\
\hline TOTAL (RM) & 610 & 170 & 264 & 408 & 182 \\
\hline
\end{tabular}

\subsubsection{Allocation for shelter in Haddul Kifayah}

In the provision of haddul kifayah, MAIWP [3] allocated a total of RM310 and RM610 for a head household living in a free house and rented house, respectively. Table 5 shows details on the calculations to develop the amount:

Table 5. Details on the calculations to develop the amount of haddul kifayah for head househol

\begin{tabular}{|c|c|c|}
\hline \multirow{2}{*}{ Basic Needs } & \multicolumn{2}{|c|}{ Head Household (RM) } \\
\cline { 2 - 3 } & Rent & Free House \\
\hline Shelter/accommodation & $\mathbf{3 0 0}$ & - \\
\hline Food & 120 & 120 \\
\hline Clothing & 30 & 30 \\
\hline Medical & 20 & 20 \\
\hline Education & - & - \\
\hline Transportation & 140 & 140 \\
\hline TOTAL & $\mathbf{6 1 0}$ & $\mathbf{3 1 0}$ \\
\hline \multicolumn{2}{|c|}{ Source: MAIWP [3] }
\end{tabular}

Table 5 shows that from the amount of RM610 allocated for the head household, the assigned value for shelter/accommodation in haddul kifayah is RM300.00. The amount represents the allocation for shelter calculated in haddul kifayah

Meanwhile, the Household Expenditure Survey (HES) [8], published by the Department of Statistics (DOS) Malaysia has listed detail components related to shelter. They are: i)Rental, ii)Maintenance or repair, iii)Water, iv)Refuse collection, v)Sewerage collection, vi)Electricity, vii)Gas, viii)Liquid fuels, and ix)Other Fuels.

The corresponding monetary allocations are subjected to the results of survey conducted. However, the amounts allocated are based on the mean monthly household consumption expenditure by states without the segregation of income level of the households. On the contrary, haddul kifayah is based on the survey on the cost of living incurred by asnaf faqr and miskin, conducted by SIRCs. Therefore, HES monetary data is unable to be used as basis for comparison in the study.

\section{Methodology}

The methodology employed for the study began with desk study, i.e; in-depth reviews of literatures on zakat, particularly those related to haddul kifayah. These include reports and relevant published documents by MAIWP [3-4] and JAWHAR [2]. Based on the literature reviews, questionnaires were designed for the study. The questionnaire was divided into 2 sections; Section A (demographic Data - Background of respondents), and Section B (Household expenditures related to shelter). Afterwards, survey amongst households who reside in houses considered suitable for the provision of shelter or housing for asnaf faqr and asnaf miskin was conducted. The survey is aimed to establish whether the houses, utilities and facilities thereto and the associated monthly costs are appropriate and sufficient or otherwise.

Based on review of literatures [2-6], [8] the authors developed a detail list of sub-components by considering the basic components of shelter that are related to the cost of living.

Table 6. The list of sub-components related to shelter

\begin{tabular}{|c|c|}
\hline No. & Sub-components \\
\hline 1 & Rental \\
\hline 2 & Housing loan \\
\hline 3 & Electricity \\
\hline 4 & Water supply \\
\hline
\end{tabular}




\begin{tabular}{|c|c|}
\hline 5 & Telephone \\
\hline 6 & Sewerage water treatment - Indah Water \\
\hline 7 & Internet \\
\hline 8 & Cable channel - Astro \\
\hline 9 & Maintenance \\
\hline 10 & Quit rent (Twice a year) \\
\hline 11 & Tax (annually) \\
\hline 12 & Joint Management Committee fee \\
\hline
\end{tabular}

The above list forms parts of the questionnaire survey (Section B). The selected respondents were then asked about the corresponding monthly expenses of all the components listed, incurred by them.

\subsection{Feedbacks from the survey}

The survey was carried out through face to face interviews with 112 head households who reside at three People's Housing Program (Projek Perumahan Rakyat (PPR)) within the federal territory of Kuala Lumpur, i.e; PPR Sg Bonus, PPR Jelatek and PPR Gombak Setia. There are a total of 29 PPR projects listed [9]. The three projects were selected based on its convenient location and the respondents were approached thorough snowball sampling. The housing projects are considered appropriate since the projects are allocated by the government for those in low income groups, with total monthly household earning amounting below RM3,000.00 [10].

In addition, MAIWP [11] stated that most of PPR residents are among the recipients of zakat fund financial assistance. Hence, the residents are deemed as meeting the requirement of suitable respondents for the study. The survey was carried out in May 2017.

Responses collected were analysed by adopting descriptive statistics, whereby the mean of each variable was calculated by using Microsoft Excel.

\section{Results and Discussion}

\subsection{Results}

From the 112 respondents, results on demographic data are shown in Table 7 .

Table 7. Results on demographic data

\begin{tabular}{|c|c|c|}
\hline No & Item & Result \\
\hline 1 & Gender & $\begin{array}{l}\text { Male: } 78(70 \%) \\
\text { Female: } 34(30 \%)\end{array}$ \\
\hline 2 & Household members & $\begin{array}{l}\text { 1-2 members: } 13(12 \%) \\
3-4 \text { members: } 55(49 \%) \\
\text { 5-6 members: } 41(37 \%) \\
>6 \text { members: } 3(2 \%)\end{array}$ \\
\hline 3 & Employment & $\begin{array}{l}\text { Employed: } 63(56 \%) \\
\text { Unemployed: } 36(32 \%) \\
\text { Retiree: } 13(12 \%)\end{array}$ \\
\hline 4 & Zakat fund recipients & $\begin{array}{l}\text { Recipient: } 27(24 \%) \\
\text { Non-recipient: } 85(76 \%) \text {. }\end{array}$ \\
\hline 5 & Ownership of house & $\begin{array}{l}\text { Rent: } 96(86 \%) \\
\text { Housing loan: } 16(14 \%)\end{array}$ \\
\hline
\end{tabular}

The results also indicated that the mean value of income is RM1, 410.71 (total), RM1, 064.81 (zakat recipients), RM1, 520.59 (non-zakat recipients).

Table 8. Results on the expenses of sub-components related to shelter/accommodation

\begin{tabular}{|c|l|r|c|c|}
\hline \multirow{2}{*}{ No. } & \multirow{2}{*}{ Sub-components } & \multicolumn{3}{|c|}{ Mean (RM) } \\
\cline { 3 - 5 } & & Total & Rent & Loan \\
\hline 1 & Rental & 124.00 & 124.00 & - \\
\hline 2 & Housing loan & 331.88 & - & 331.88 \\
\hline 3 & Electricity & 87.67 & 86.14 & 96.88 \\
\hline 4 & Water supply & 32.54 & 31.21 & 40.50 \\
\hline 5 & Telephone & 47.84 & 46.63 & 56.40 \\
\hline 6 & $\begin{array}{l}\text { Sewerage water } \\
\text { treatment - Indah } \\
\end{array}$ & 45.00 & 45.00 & - \\
\hline 7 & Water & & & \\
\hline 8 & Cabternet channel - Astro & 87.65 & 88.78 & 80.00 \\
\hline 9 & Maintenance & 45.00 & 70.03 & 68.85 \\
\hline & Total & $\mathbf{3 9 6 . 6 7}$ & $\mathbf{3 6 3 . 5 8}$ & $\mathbf{6 0 3 . 0 0}$ \\
\hline
\end{tabular}

Table 8 shows the mean value for each of the expenses of the identified sub-components of shelter. Apart from mean value of the total survey, results are also segregated between the mean value of expenses incurred by those renting the house and those paying housing loan.

It has to be noted here that the number of respondents for every component is different. This is due to the fact that not all respondents answer all the questions related to their expenditures on subcomponents related to shelter as listed in the questionnaire. Hence, the outcome of the survey should be evaluated accordingly.

\subsection{Discussion}

Table 9. Comparison between allocation for shelter in haddul kifayah and results from the survey

\begin{tabular}{|c|c|c|c|}
\hline Haddul kifayah & \multicolumn{3}{|c|}{ Results of the survey } \\
\cline { 2 - 4 } & Total & Rental & Housing loan \\
\hline RM300.00 & RM396.67 & RM363.58 & RM603.00 \\
& $(32 \%)$ & $(21 \%)$ & $(101 \%)$ \\
\hline
\end{tabular}

Results from the survey in Table 9 suggested that the amount allocated under the haddul kifayah for shelter by MAIWP is lower; the actual total cost is at $32 \%$ higher. Differences in the cost of shelter are apparent between those who are paying rental cost and those who are paying/servicing housing loan, $21 \%$ and $101 \%$, respectively, higher than the amount in haddul kifayah.

From the total cost of shelter, other than the rental or loan, electricity consumption contributes towards the highest proportion of the total cost, followed by internet, cable channel, telephone bill, sewerage water treatment and maintenance.

None of the respondents provide input on the cost for assessment tax, quit rent and joint management committee fee, indicating that those sub-components identified are not relevant to them, given that they are residing in the multi-storey PPR housing, However, the 
cost such as assessment tax and quit rent are relevant to those who are living on landed low cost housing.

The authors are unable to compare the findings from the survey on the monetary allocations for each subcomponent with the current allocations adopted by MAIWP. This is because it seems that published literature on the detail calculations is lacking. Thus, it is not clear how the total amount of RM300.00 allocated for the sub-components forming the housing component is established.

\section{Conclusion}

This paper reported on a study focusing on the shelter in the haddul-kifayah. The objectives are:

i) To identify the sub-components for the shelter in the haddul-kifayah and the monetary allocations corresponding thereto, and;

ii) To examine whether the identified sub-components and the monetary allocations corresponding thereto are appropriate and sufficient in meeting the current basic needs of shelter by the asnaf faqr and asnaf miskin respectively.

From the desk study and the questionnaire survey conducted, this paper identified a list of sub-components that are deemed appropriate in forming the shelter components of the haddul kifayah.

In addition, the study indicated that the subcomponents forming the shelter in the haddul kifayah and the monetary allocations corresponding thereto as currently being adopted by MAIWP are neither appropriate nor sufficient in meeting the current needs of the asnaffaqr or asnaf miskin, respectively.

Consequently, it is deemed appropriate to propose for zakat authorities to cogitate in revising the standards applied in determining the appropriateness and sufficiency of the sub-components forming the shelter in the haddul-kifayah. The result from the study can serve as an impetus for a comprehensive and national study on the provision of haddul kifayah for shelter to be conducted.

The study has been able to emphasize the significance of multi-disciplinary approach in conducting research. As in this case, the study involved issues related to socio-economy within the context of Islam. Past studies were mostly conducted from the perspective of Islam only, i.e; focussing on zakat with very limited exposure on issues related to social and economy of the Muslim communities and others.

In addition, the fact that the study concerns issues about the provision of shelter and its affordability as viewed from the perspective of zakat would therefore be useful to be further explored from the perspective of the construction industry. This is due to the fact that the provision of shelter is the domain of the construction industry. Hence, the outcome of the current study should be viewed with importance by researchers, practitioners and policy makers of the construction industry.
The study is not without limitation and the idea presented herein is still at its infancy. Hence, further and in-depth study is required and on-going.

The study reported in this paper is funded by the Transdisciplinary Research Grant (Project ID: TRGS16-01 002-0002), Ministry of Higher Education Malaysia: Developing a Framework for Determining the Adequacy, Currency and Sufficiency of Haddul Kifayah in the Provision of Housing for the Ummah. In addition to the authors, the following are also involved with the study:

1) Associate Professor Dr. Azila Ahmad Sarkawi,

2) Assistant Professor Ar. Dr. Srazali Aripin and,

3) Assistant Professor Dr. Puteri Nur Farah Naadia Mohd Fauzi

\section{References}

1. Department of Islamic Development Malaysia. Tafsir Ar-Rahman Interpretation of the Meaning of the Qur'an, JAKIM, Malaysia (2007)

2. Jabatan Wakaf, Zakat dan Haji (JAWHAR). 'Manual Pengurusan Agihan Zakat,' Putrajaya. (2009)

3. MAIWP, 'Buku Panduan Proses Permohonan Skim-Skim Bantuan Zakat Baitulmal,' (n.d) [Online]. Available: http://www.maiwp.gov.my/i/index.php/perkhidmata n-kami/muat-turun/category/24-buku-terbitan [Accessed July 20, 2018]

4. MAIWP. Haddul Kifayah (2018) [Online]. Available: https://www.maiwp.gov.my/ [Accessed July 20, 2018]

5. Khairuddin, A.R., Sharina Farihah, H., Azila, A. S. Haddul Kifayah: Its comprehensiveness, sufficiency and currency in meeting the needs of the asnaf faqr and asnaf miskin, Proceedings of the National Conference on Zakat and Economic Development 2015, 1st June 2015, UMP, Kuantan, Pahang (2015)

6. Khairuddin, A.R., Sharina Farihah, H., Azila, A. S. Assessing The Appropriateness And Adequacy Of The Provision For Housing Under The HaddulKifayah For Asnaf Faqr And Asnaf Miskin. Proceedings of the 3rd Asean International Conference on Islamic Finance (AICIF), Semarang, Indonesia on 17th - 19th November 2015. (2015).

7. Islam Online From Europe. 'Fiqh As-Sunnah: Zakah "giving Alms". [Online]. Available: http://islamiska.org/e/z11.htm [Accessed May 15, 2015]

8. Department of Statistics Malaysia. Report on Household Expenditure Survey 2016. (2016) [Online], Available: https://www.dosm.gov.my/ [Accessed July 20, 2018]

9. Kuala Lumpur City Hall, 'Perumahan Awam', (2018) [Online], Available: http://www.dbkl.gov.my/ [Accessed September 11, 2018],

10. Ministry of Urban Wellbeing, Housing and Local Government, People's Housing Programme, (2018) [Online], Available: http://www.kpkt.gov.my/ [Accessed July 20, 2018] 
11. MAIWP. Laporan Tahunan MAIWP 2013 ,

(2015), [Online], Available:

https://www.maiwp.gov.my/i/index.php/en/lap oran-tahunan-maiwp [Accessed August 27, 2015] 
http://www.maiwp.gov.my/i/index.php/perkhidmata

n-kami/muat-turun/category/23-laporan-tahunan. 